\title{
KERANGKA ACUAN KERJA MERUPAKAN BAGIAN PENTING YANG MEMPENGARUHI KETERLAMBATAN KERJA PADA PROYEK PEMBANGUNAN DOM UNISMA
}

\author{
Ruli Saefudin'1, Lalu Mulyadi ${ }^{2}$, Tiong Iskandar ${ }^{3}$, dan Lies K Wulandari ${ }^{4}$. \\ 1,2,3,4 Program Pascasarjana ITN Malang, Jalan Sigura-gura Malang \\ Email: rulisaefudin@gmail.com
}

\begin{abstract}
ABSTRAK
Strategi yang harus dilakukan kontraktor dengan keterbatasan Lingkungan kerja yang sempit yaitu membuat Cetakan Tribun di luar Area, Membuat Kerangka Atap di luar Area. Dan membuat Cetakan Kusen di luar Area. sediakan shop drawing untuk membuat kerangka acuan kerja (KAK) dan spesifikasi teknis sesuai dengan perencanaan yang lebih lengkap dan teliti serta mengikuti dan mengejar ketinggalan time scedulle kurva $\mathrm{S}$ yang sudah ditentukan, Menyelesaikan dengan perencanaan yang lebih lengkap dan teliti, Mapping suatu pekerjaan untuk membuat analisa baik dalam penggunaan peralatan, bahan ataupun tenaga sehingga tepat waktu, mutu dan biaya.
\end{abstract}

Kata Kunci : KAK,keterlambatan Proyek, Dom Unisma.

\section{PENDAHULUAN}

Proyek konstruksi selalu menghadapi beberapa kendala, baik itu kendala yang sudah diperkirakan sebelumnya, maupun yang diluar perkiraan. Kendala biasanya menjadi penyebab terhambatnya pelaksanaan pekerjaan, sehingga pekerjaan tidak berlangsung dengan lancar. Oleh karena itu, dalam pelaksanaan proyek konstruksi ada kemungkinan waktu yang dibutuhkan untuk menyelesaikan akan melebihi waktu yang telah ditentukan dalam kontrak pekerjaan atau dengan kata lain terjadi keterlambatan waktu proyek.

Keterlambataan proyek menjadi kontribusi utama terhadap terjadinya pembengkakan biaya proyek. Secara umum keterlambatan proyek sering terjadi karena adanya perubahan perencanaan selama proses pelaksanaan, manajerial yang buruk dalam organisasi kontraktor, rencana kerja yang tidak tersusun dengan baik/terpadu, gambar dan spesifikasi yang tidak lengkap, dan kegagalan kontraktor dalam melaksanakan pekerjaan. Keterlambatan proyek juga terjadi pada Pembangunan Gedung Pembangunan gedung Kuliah, Laboratorium dan Auditorium Universitas Islam Malang (DOM UNISMA), dimana proyek yang dibangun ini dalam pelaksanaannya tidak memenui target tepat waktu yang di harapkan. Itu terbukti dengan terlihatnya bangunan yang belum selesai dibangun mengalami keterlambatan mencapai $8 \%$ dari waktu yang telah ditentukan. Dimana keterlambatan diperkirakan diduga disebabkan oleh beberapa faktor seperti material, peralatan, tenaga kerja, keuangan, metode pelaksanaan pekerjaan, perubahan desain dan lingkungan kerja. Keterlambatan tersebut umumnya selalu menimbulkan akibat yang merugikan baik bagi pemilik maupun kontraktor, karena dampak keterlambatan adalah konflik dan perdebatan tentang apa dan siapa yang menjadi penyebab juga tuntutan waktu dan biaya tambah. Pengertian keterlambatan menurut Ervianto (2004) adalah sebagai waktu pelaksanaan yang tidak dimanfaatkan sesuai dengan rencana kegiatan sehingga menyebabkan satu atau beberapa kegiatan mengikuti menjadi tertunda atau tidak diselesaikan tepat sesuai jadwal yang telah direncanakan. Dalam bagian ini akan diterangkan beberapa pendapat para ahli mengenai penyebab-penyebab keterlambatan. Keterlambatan pada proyek konstruksi dapat di golongkan menjadi 2 (dua) kelompok (Ervianto 2004), yaitu: excusable delay dan nonexcusable delay.

\section{Excusable delay}

Excusable Delay, adalah gagalnya pihak pengelola konstruksi menepati waktu penyelesaian sesuai denganperjanjian yang telah disepakati. Penyebab kegagalan pada proyek ini adalah permasalahan desaign, perubahan pekerja oleh pemilik proyek, pengaruh cuaca, perelisihan pekerja dan bencana alam.

a. Compensable \& Noncompensable Excusable delay dapat dikelompokkan kedalam compensable maupun Noncompensable. Jika keterlambatan masuk dalam kategori compensable maka pihak yang di rugikan akan mendapat tambahan waktu dan biaya ganti rugi sesuai dengan analisis yangtelah disepakati

b. Critical \& Noncritical delay Kondisi yang tidak menyebabkan terjadinya penambahan waktu penyelesaian proyek disebut Noncritical delay.Kondisi yang menyebabkan terjadinya perubahan / bertambahnya waktu penyelesaian proyek kontruksi di sebut critical delay. 


\section{Nonexcusable delay}

Nonexcusable delay, adalah suatu kondisi saat terjadi penundaan pekerjaan yang disebabkan oleh pihak pelaksana konstruksi. Penyebab kegagalan pada kelompok ini adalah perencanaan pelaksanaan yang tidak tepat oleh kontraktor, ketidak mampuan sumber daya manusia yang dimiliki kontraktor, kegagalan sub kontraktor. Dan ini bisa berakibat pemutusan hubungan kontrak/kerja. Pada umumnya tidak akan pernah mendapatkan perpanjangan waktu akan tetapi kontraktor akan melakukan markup dalam scedule dengan melakukan percepatan pekerjaan.

Menurut istimawan Dipohusodo (1996), selama proses kontruksi selalu saja muncul gejala kelangkaan periodik atas material-material yang diperlukan, berupa material dasar atau barang jadi baik yang lokal maupun Import. Cara penangananya sangat bervariasi tergantung pada kondisi proyek, sejak yang ditangani langsung oleh staf kusus dalam organisasi sampai bentuk pembagian porsi tanggung jawab diantara pemberi tugas, Kontraktor dan sub kontraktor, sehingga penawaran material suatu proyek dapat datang dari sub-kontraktor, pemasok atau agen, importer, produsen atau industri, yang kesemuanya mengacu pada dokumen perencanaan dan spesifikasi teknis yang telah ditetapkan. Cara mengendalikan keterlambatan adalah;

1. Mengerahkan sumberdaya tambahan

2. Melepas rintangan-rintangan, ataupun upaya-upaya lain untuk menjamin agar pekerjaan meningkat dan membawa kembali kegaris rencana.

3. Jika tidak mungkintetap pada garis rencana semula mungkin diperlukan revisi jadwal, yang untuk selanjutnya dipakai sebagai dasar penilaian kemajuan

Populasi adalah merupakan wilayah generalisasi yang terdiri dari obyek/subyek yang memiliki kuantitas dan karakteristik tertentu yang ditetapkan oleh peneliti untuk dipelajari dan kemudian ditarik kesimpulannya.Yang dimaksud dengan populasi adalah kumpulan seluruh individu dengan kualitas yang telah ditetapkan, kualitas atau ciri tersebut dinamakan variabel. Sebuah populasi dengan jumlah individu tertentu disebut populasi finit. Pengertian populasi yang lain adalah keseluruhan subjek atau totalitas subjek penelitian yang dapat berupa; orang, benda, / suatu hal yang di dalamnya dapat diperoleh dan atau dapat memberikan informasi (data).

Yang dimaksud dengan sampel adalah kumpulan dari unit sampling yang ditarik dan merupakan sub dari populasi. Sampel adalah sebagian dari jumlah dan karakteristik yang dimiliki oleh populasi tersebut, ataupun bagian kecil dari anggota populasi yang diambil menurut prosedur tertentu sehingga dapat mewakili populasinya.. Dimana orang-orang tersebut berada didalam masing-masing instansi/perusahaan. Sedangkan sampel diambil dari populasi yang dianggap mewakili semua instansi/perusahaan tersebut (Sugiyono, 2006).

Statistik adalah cara untu mengolah data dan menarik kesimpulan-kesimpulan yang teliti dan keputusankeputusan yang logik dari pengolahan data. (Prof.Drs.Sutrisno Hadi,MA). Jadi secara singkat statistik dapat diartikan, sebagai cara maupun aturan-aturan yang berkaitan dengan pengumpulan, pengolahan (analisis), penarikan kesimpulan, atas data-data yang berbentuk angka-angka, dengan menggunakan suatu asumsi-asumsi tertentu. Statistika adalah pengetahuan yang berkaitan dengan metode, teknik atau cara mengumpulkan, mengolah, menganalisis dan menginterprestasikan data untuk disajikan secara lengkap dalam bentuk yang mudah dipahami penggunan

Validitas berasal dari kata validity yang mempunyai arti sejauh mana ketepatan dan kecermatan suatu alat ukur dalam melakukam fungsi ukurannya (Azwar 1986)..Uji validitas adalah uji yang digunakan untuk menunjukkan sejauh mana alat ukur yang digunakan dalam suatu mengukur apa yang diukur. Ghozali (2009).

Validitas item ditunjukkan dengan adanya korelasi atau dukungan terhadap item total (skor total), perhitungan dilakukan dengan cara mengkorelasikan antara skor item dengan skor total item. Bila kita menggunakan lebih dari satu faktor berarti pengujian validitas item dengan cara mengkorelasikan antara skor item dengan skor faktor, kemudian dilanjutkan mengkorelasikan antara skor item dengan skor total faktor (penjumlahan dari beberapa faktor).

Dari hasil perhitungan korelasi akan didapat suatu koefisien korelasi yang digunakan untuk mengukur tingkat validitas suatu item dan untuk menentukan apakah suatu item layak digunakan atau tidak. Dalam penentuan layak atau tidaknya suatu item yang akan digunakan, biasanya dilakukan uji signifikansi koefisien korelasi pada taraf signifikansi 0,05, artinya suatu item dianggap valid jika berkorelasi signifikan terhadap skor total.

Analisa faktor merupakan suatu analisis yang digunakan untuk mereduksi atau meringkas dari banyak faktor kedalam satu atau beberapa faktor, yang paling dominan atau berpengaruh. Model analisis faktor menurut Malhorta (1996) dapat dirumuskan sebagai berikut :

$$
X i=A_{i j} F_{1}+A_{i 2} F_{2}+A_{i 3} F_{3}+\ldots \ldots . . .+A_{i m} F_{m}+V_{i} U_{i}
$$

Dimana :

$\mathrm{Xi} \quad=$ variabel terstandar $\mathrm{ke} \mathrm{i}$

$\mathrm{A}_{\mathrm{ij}} \quad=$ koefisien regresi dari variabel ke i pada common faktor $\mathrm{j}$

$\mathrm{F} \quad=$ common factor

$\mathrm{Vi}=$ koefisien regresi terstandar dari variabel i pada faktor unik ke-i

$\mathrm{Ui} \quad=$ faktor unik untuk variabel ke $\mathrm{i}$

M = jumlah common factor 
Analisa faktor merupakan perluasan dari analisis komponen utama. Analisis faktor digunakan untuk menggambarkan hubungan korelasi dari beberapa variabel dalam sejumlah kecil faktor. Variabel-variabel ini dikelompokkan menjadi beberapa faktor dimana variabel-variabel dalam satu faktor akan mempunyai korelasi yang tinggi, sedangkan korelasinya dengan variabel-variabel pada faktor lain relatif rendah. Pada dasarnya analisis faktor bertujuan untuk mendapatkan sejumlah faktor yang memiliki sifat-sifat sebagai berikut :

1. Mampu menerangkan semaksimal mungkin keragaman data.

2. Faktor-faktor saling bebas.

3. Setiap faktor dapat diinterpretasikan.

Jadi, analisis faktor bertujuan untuk menemukan suatu cara meringkas (summarize) informasi yang ada dalam variabel asli (awal) menjadi satu set dimensi baru atau variate (factor). Hal ini dilakukan dengan cara menentukan struktur lewat data summarization atau lewat data reduction (pengurangan data). Analisis factor mengidentifikasi struktur hubungan antar variabel atau responden dengan cara melihat korelasi antar variabel atau korelasi antar responden. Vektor random $X$ yang diamati dengan $p$ buah variabel komponen, secara linier bergantung atas sejumlah variabel random yang dapat teramati yaitu $F_{1}, F_{2}, F_{q}$ dan $\varepsilon_{1}, \varepsilon_{2}$ $\varepsilon_{q}$ sehingga secara luasan dapat ditulis sebagai berikut :

$$
\begin{aligned}
& X_{1}=L_{11 .} F_{1}+L_{12 .} F_{2}+\ldots \ldots \ldots \ldots \ldots \ldots \ldots \ldots . .+L_{l q .} F_{q}+\varepsilon_{1} \\
& X_{2}=L_{21} F_{1}+L_{22} F_{2}+\ldots \ldots \ldots \ldots \ldots \ldots \ldots \ldots . .+L_{2 q .} F_{q}+\varepsilon_{2} \\
& X_{p}=L_{p 1 .} F_{1}+L_{p 2} F_{2}+\ldots \ldots \ldots \ldots \ldots \ldots \ldots \ldots+L_{p q .} F_{q}+\varepsilon_{p}
\end{aligned}
$$

Dimana :

$\mathrm{F}_{\mathrm{j}} \quad=$ Commom factor ke $\mathrm{j}$

$\mathrm{L}_{\mathrm{ij}} \quad=$ Loading variabel ke $\mathrm{i}$ pada faktor $\mathrm{ke} \mathrm{j}$

$E_{i} \quad=$ Specific faktor $k e i, i=1,2, \ldots \ldots . . p$ dan $j=1,2$.......... $q$

Dalam matrix di atas dapat ditulis sebagai berikut :

$$
X_{(p x l)}=L_{(p x q)} \cdot F_{(p x l)}+\varepsilon_{(p x l)}
$$

Dengan asumsi :

$F$ dan $\varepsilon$ saling bebas, sehingga $\operatorname{Cov}(F, \varepsilon)=O_{(p \times q)}$

$E(F)=O_{(q x)}, \operatorname{Cov}(F)=\left(F F^{\prime \prime}\right)=I_{(q x q)+}$

$\mathrm{E}\left(\varepsilon^{\prime}\right)=\mathrm{O}_{(\mathrm{pxl})}, \operatorname{Cov}(\varepsilon)=\mathrm{E}\left(\varepsilon \varepsilon^{\prime}\right)=\mathrm{Y}_{(\mathrm{pxp})}=$ Matrix Diagonal.

Faktor-faktor yang diperoleh dari analisis komponen utama pada umumnya masih sulit diinterpretasikan. Karena itu harus dilaksanakan tranformasi pada matrix loading untuk meningkatkan daya interpretasi faktor. Tranformasi matrix loading dilakukan dengan merotasi mastrix tersebut dengan metode rotasi tegak lurus varimax. Hasil rotasi ini akan mengakibatkan setiap variabel asal mempunyai korelasi tinggi dengan faktor tertentu saja dan dengan faktor yang lain korelasinya relatif rendah sehingga setiap faktor akan lebih mudah untuk diinterpretasikan. Transformasi yang dimaksud adalah tranformasi matrix loading $\mathbf{L}$ menjadi $\mathbf{L}^{*}$ adalah $L^{*}=L$. $T$ dimana $T T^{\prime}=T^{\prime} T=$ 1. matrix transformasi T ditentukan sedemikian hingga varian dari matrix loading baru menjadi maksimum

$$
\mathrm{V}=\frac{1}{\mathrm{p}} \cdot \sum_{\mathrm{i}=1}^{\omega} \cdot\left[\sum_{\mathrm{i}=1}^{\mathrm{p}}\left(1 *_{\mathrm{Y}}\right)^{1}-\frac{1}{\mathrm{p}}\left(\sum_{\mathrm{i}=1}^{\mathrm{p}}\left(1 *_{\mathrm{Y}}\right)^{2}\right)\right]
$$

Untuk tujuan pengklasifikasian, maka semua pengamatan dicari skor faktornya dengan memenuhi persamaan matrik sebagai berikut:

Dimana :

$\mathrm{Z} \quad=$ Matrix dan awal yang distandarkan.

$\mathrm{R}^{-1} \quad=$ Invers dari matrix korelasi

$\mathrm{L}=$ = Matrix Loading

$\mathrm{F} \quad=$ Matrix score faktor untuk semua observasi 
Untuk memudahkan dalam interpretasi, maka dilakukan transformasi dengan metode rotasi varimax yaitu $L^{*}=L . T$ dimana $L^{*}$ hasil tranformasi dari matrix loading $L$ dan $T^{\prime}=T^{\prime} T=1$.

\section{Kriteria ketepatan penggunaan analisis faktor}

Untuk menguji ketepatan penggunaan analisis faktor, kriteria yang bisa digunakan adalah:

\section{Keiser Meyer Olkin (KMO) (Cooper et al, 1999)}

Keiser Meyer Olkin Measure of Sampling adalah indeks perbandingan jarak antara koefisien korelasi dengan koefisien korelasi parsialnya. KMO memiliki nilai yang terletak antara 0 dan 1.Jika jumlah kuadrat koefisien korelasi parsial diantara seluruh pasangan variabel bernilai kecil jika dibandingkan dengan jumlah kuadrat koefisien korelasi, maka akan menghasilkan nilai KMO yang mendekati 1. Nilai KMO menyatakan kesesuaian penggunaan analisis faktor Nilai KMO dianggap mencukupi apabila nilai yang dihasilkan lebih besar dari 0.5 . Nilai KMO yang kecil mengindikasikan bahwa penggunaan analisis faktor harus dipertimbangkan kembali, karena korelasi antar peubah tidak dapat diterangkan oleh peubah lain. Penilaian uji KMO dari matriks antar peubah adalah sebagai berikut :

a. $0,9<\mathrm{KMO} \leq 1,0$ berarti data sangat baik untuk analisis faktor.

b. $0,8<\mathrm{KMO} \leq 0,9$ berarti data baik untuk analisis faktor.

c. $0,7<\mathrm{KMO} \leq 0,8$ berarti data cukup baik untuk analisis faktor.

d. $\quad 0,6<\mathrm{KMO} \leq 0,7$ berarti data lebih dari cukup untuk analisis faktor.

e. $0,5<\mathrm{KMO} \leq 0,6$ berarti data cukup untuk analisis faktor.

f. $\mathrm{KMO} \leq 0,5$ berarti data tidak layak untuk analisis faktor.

\section{Kriteria kecukupan sampel}

Untuk mengetahui kecukupan sampel maka kriteria yang digunakan adalah Measure of Sampling Adequacy (MSA) dalam Cooper et al, 1999

Pada dasarnya MSA merupakan KMO untuk masing-masing variabel. Total dari MSA ini merupakan nilai KMO. MSA bisa digunakan sebagai penentu untuk mengikutsertakan variabel dalam model karena variabel tersebut memiliki korelasi yang tinggi. Kriteria untuk tidak mengikutsertakan variabel dalam model sama dengan KMO. Nilai MSA berkisar antara 0 dan 1.

1. $M S A=1$, berarti variabel masih bisa diprediksi dan bisa dianalisis lebih lanjut.

2. $M S A>0.5$, berarti variabel bisa diprediksi dan bisa dianalisis lebih lanjut

3. $\mathrm{MSA}<0.5$, berarti variabel tidak bisa dianalisis dan tidak bisa dianalisis lebih lanjut, atau dikeluarkan dari variabel lainnya.

Regresi linear adalah alat statistik yang dipergunakan untuk mengetahui pengaruh antara satu atau beberapa variabel terhadap satu buah variabel. Variabel yang mempengaruhi sering disebut variabel bebas, variabel independen atau variabel penjelas. Variabel yang dipengaruhi sering disebut dengan variabel terikat atau variabel dependen. Model Persamaan Regresi Linear berganda tidak jauh dengan regresi linear Sederhana adalah. Sebelum kita mengenal regresi linear berganda langkah baiknya kita mengenal regresi linear sederhana, agar pemahaman kita lebih mudah seperti berikut ini :

$$
Y=a+b X
$$

Dimana:

$\mathrm{Y}=$ Variabel Response atau Variabel Akibat (Dependent)

$\mathrm{X}=$ Variabel Predictor atau Variabel Faktor Penyebab (Independent)

$\mathrm{a}=$ konstanta

$\mathrm{b}=$ koefisien regresi (kemiringan); besaran Response yang ditimbulkan oleh Predictor.

Analisis Regresi adalah analisis yang mengukur pengaruh variabel bebas terhadap variabel terikat. Pengukuran pengaruh ini melibatkan satu variabel bebas $(X)$ dan variabel terikat $(Y)$, yang dinamakan analisis regresi linier sederhana dengan rumus $Y=a+b X$. Nilai " $a$ " adalah konstanta dan nilai " $b$ " adalah koefisien regresi untuk variabel $X$. Harga 'a' dapat dicari dengan rumus:

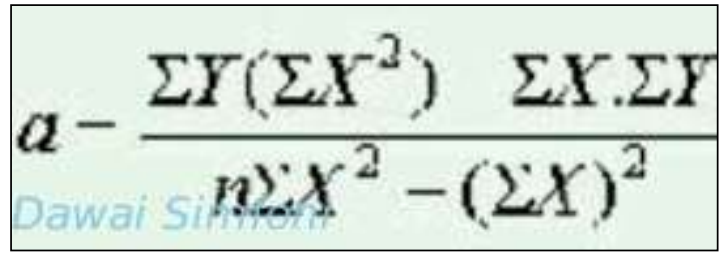

Gambar 1. Rumus Variabel a 
Harga ' $b$ ' dapat dicari dengan rumus:

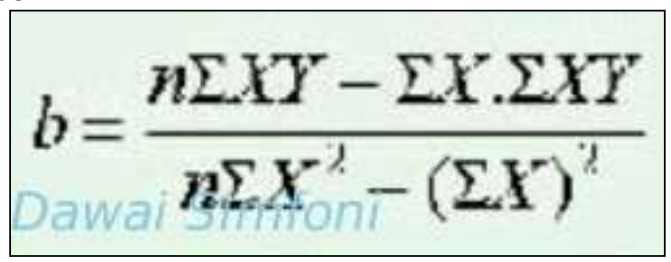

Gambar 2. Rmus Variabel b

Koefisien regresi ' $b$ ' adalah kontribusi besarnya perubahan nilai variabel bebas, semakin besar nilai koefisien regresi maka kontribusi perubahan semakin besar, demikian pula sebaliknya akan semakin lecil. Kontribusi perubahan variabel bebas $(X)$ juga ditentukan oleh koefisien regresi positif atau negatif.

Analisis regresi linier berganda merupakan salah satu analisis yang digunakan untuk mengetahui bentuk hubungan atau pengaruh antara beberapa variabel bebas terhadap variabel terikat. Secara umum, menurut Solimun (2006), ada 3 manfaat yang dapat diambil dari persamaan regresi, di antaranya adalah:

1. Penjelasan (explanation), yakni menjelaskan fenomena atau permasalahan yang diteliti, bagaimana bentuk hubungan atau pengaruh antara variabel-variabel bebas dan variabel terikat.

2. Prediksi (prediction), yakni memprediksi nilai variabel terikat berdasarkan nilai variabel bebas yang diketahui, yang mana prediksi dengan regresi ini dapat dilakukan secara kuantitatif

3. Faktor determinan (determinan faktor), yakni menentukan variabel bebas mana (regresi berganda) yang berpengaruh dominan terhadap variabel terikat. Hal ini dapat dilakukan bila unit unit satuan dan skala data seluruh variabel relatif sama.

Dalam penelitian ini, peneliti membatasi tujuan penelitian ini hanya pada dua tujuan regresi linier berganda di atas, yakni ingin mengetahui bentuk hubungan/pengaruh antara variabel-variabel bebas dengan variabel terikat. Selain itu, peneliti juga ingin mengetahui variabel bebas mana yang paling berpengaruh terhadap variabel terikat. Penelitian ini tidak ditujukan untuk tujuan prediksi atau peramalan terhadap nilai variabel terikat berdasarkan nilai variabelvariabel bebas yang telah diketahui.

Untuk mengetahui faktor yang paling berpengaruh terhadap suatu variabel digunakan teknik analisis regresi dengan melihat angka koefisien regresi yang paling besar, uji $F$ (ANOVA) untuk model regresi secara simultan, uji $t$ untuk model regresi secara parsial, Nilai $R^{2}$ (koefisien determinasi). Faktor internal adalah variabel bebas yang mempengaruhi variabel terikat.

Hubungan antara variabel terikat dan variabel-variabel bebas dapat dinyatakan dengan rumus :

$$
Y=a+b_{1} X_{1}+b_{2} X_{2}+b_{3} X_{3} \ldots . .+b_{n} X_{n}
$$

dimana:

$Y=$ Subyek dalam variabel dependen yang diprediksikan

$X_{n}=$ Subyek data variabel independen yang mempunyai nilai tertentu.

$a=$ Harga $Y$ bila $X=0$ (Harga Konstanta)

$b_{n}=$ Angka arah atau koefisien regresi yang menunjukkan angka

Peningkatan ataupun penurunan variabel independen yang didasarkan pada variabel independent. Bila b $(+)$ maka naik, dan bila (-) maka terjadi penurunan.

Hipotesis diartikan sebagai jawaban sementara terhadap rumusan masalah penelitian. Kebenaran dari hipotesis itu harus dibuktikan melalui data yang terkumpul. Pengertian hipotesis tersebut adalah untuk hipotesis penelitian. Sedangkan secara statistik hipotesis diartikan sebagai pernyataan mengenai keadaan populasi (parameter) yang akan diuji kebenarannya berdasarkan data yang diperoleh dari sampel penelitian (statistik). Oleh karena itu dalam statistik yang diuji adalah hipotesis nol. Jadi hipotesisi nol adalah pernyataan tidak adanya perbedaan antara parameter dengan statistik (data sampel). Lawan dari hipotesis nol adalah hipotesis alternatif, yang menyatakan adanya perbedaan antara parameter dan statistik. Hipotesis nol diberi notasi Ho, dan hipotesis alternatif diberi notasi Ha (Sugiyono, 2006). Uji hipotesis statistik digunakan untuk memberikan jawaban sementara terhadap rumusan penelitian Asumsi Multikolinearitas

Multikolinearitas berarti adanya hubungan linier yang "sempurna" atau pasti di antara beberapa atau semua variabel yang menjelaskan dari regresi. Metode yang digunakan untuk mendeteksi adanya multikolinearitas adalah dengan menggunakan tolerance and variance inflation factor (VIF). Rule of thumb digunakan sebagai pedoman jika VIF dari suatu variabel melebihi 10, dimana hal ini terjadi ketika nilai $R^{2}$ melebihi 0,90 maka suatu variabel dikatakan berkorelasi sangat tinggi. Besarnya VIF dirumuskan sebagai berikut (Aliman, 2000) :

$$
V I F=\frac{1}{\left(1-R_{x t}^{2}\right)}
$$

Asumsi Homoskedastisitas 
Suatu asumsi penting dari model regresi linier klasik adalah bahwa gangguan (disturbance) yang muncul dalam regresi adalah homoskedastisitas, yaitu semua gangguan tadi mempunyai varian yang sama. Secara matematis asumsi ini dapat dituliskan sebagai berikut (Gujarati, 1995):

$$
\begin{array}{r}
E\left(u_{I}\right)=\sigma^{2} \\
i=1,2,3, \ldots, \ldots \ldots \ldots \ldots \ldots \ldots
\end{array}
$$

Adapun metode yang akan dibahas disini yaitu metode Korelasi Rank Spearman. Koefisien korelasi Spearman dirumuskan :

$$
\mathrm{r}_{\mathrm{s}=1-6} \frac{\sum d_{i}^{2}}{N\left(N^{2}-1\right)}
$$

di mana $d_{i}=$ selisih dari Xi dengan $\mathrm{N}=$ banyaknya individu.

\section{METODE PENELITIAN}

\section{Metode pengolahan dan analisa data}

Dalam penelitian kualitatif diperlukan suatu ketepatan dalam pengujian tiap variabel yang telah diidentifikasi. Ketepatan pengujian suatu hipotesis mengenai variabel penelitian ini sangat bergantung pada kualitas data yang dipakai dalam pengujian tersebut. Data penelitian ini tidak akan berguna jika instrumen atau pengukur penelitian yang akan dipakai untuk mengumpulkan data instrumen yang dipersiapkan untuk mengumpulkan data tersebut tidak memiliki vaiditas dan reabilitas. Seringkali peneliti berpikir apakah instrumen yang dipersiapkan untuk mengumpulkan data penelitian benar-benar mengukur apa yang ingin diukur. Maka dari itu, diperlukan suatu pemahaman terhadap validitas dan reabilitas instrumen penelitian.Data yang diperoleh dari hasil survei (kuesioner) nantinya diolah untuk memperoleh informasi dalam bentuk tabel.

\section{Analisis regresi linier berganda}

Untuk menguji pertanyaan-pertanyaan yang berkaitan dengan faktor-faktor yang mempengaruhi keterlambatan pelaksanaan pekerjaan pada Proyek Pembangunan Gedung Kuliah, Laboratorium Dan Auditorium Universitas Islam Malang (DOM Unisma) dan mendapatkan faktor yang paling dominan mempengaruhinya, teknik analisis yang digunakan adalah uji regresi linier berganda. Uji ini digunakan untuk menguji atau menganalisis pengaruh atau hubungan antara variabel bebas dengan satu atau lebih variabel, dalam teknik analisis digunakan uji annova atau uji $\mathrm{f}$, uji t dan mencari besar koefisien determinasi atau $\mathrm{R}^{2}$ adjusted perhitungan ini akan dilakukan dengan bantuan program SPSS sesuai persamaan linear berganda :

dimana :

$$
Y=b_{0}+b_{1} X_{1}+b_{2} X_{2}+b_{3} X_{3}+b_{4} X_{4}+b_{5} X_{5}+b_{6} X_{6}+b_{7} X_{7}
$$

$\mathrm{Y}=$ Keterlambatan Pelaksanaan Pekerjaan

$\mathrm{X} 1=$ Keuangan

$\mathrm{X}_{2}=$ Material

$\mathrm{X} 3=$ Tenaga Kerja

$\mathrm{X} 4=$ Peralatan

$\mathrm{X5}=$ Metode Pelaksanaan

$\mathrm{X} 6=$ Perubahan Desain

$\mathrm{X7}=$ Lingkungan Kerja

$\mathrm{b}_{0} \quad=$ Konstanta

$b_{1}, b_{2}, b_{3}, b_{4}, b_{5}, b_{6}, b_{7}=$ Koefisien Regresi

\section{Uji hipotesis koefisien model regresi}

Untuk membuktikan kebenaran hipotesis digunakan Uji F dengan kriteria pengujian sebagai berikut :

\section{Hipotesa :}

$\mathrm{H}_{\mathrm{o}}=$ tidak ada perbedaan indeks produktivitas antar kelompok.

$\mathrm{H}_{1}=$ ada perbedaan indeks produktivitas antar kelompok.

b. Pengambilan kesimpulan didasarkan pada nilai Probabilitas :

- Jika Probabilitas $>0,05$, maka $\mathrm{H}_{0}$ diterima.

- Jika Probabilitas <0,05, maka $\mathrm{H}_{0}$ ditolak. 


\section{JURNAL INFOMANPRO}

Pengaruh variabel bebas secara simultan terhadap variabel terikat. Uji F digunakan untuk menguji variabel-variabel bebas secara bersama-sama terhadap variabel terikat. Pengujian ini dilakukan dengn membandingkan nilai $F_{\text {hitung }}$ dengan nilai $F_{\text {tabel }}$ atau perbandingan nilai sig F. Ketentuan dari penerimaan atau penolakan hipotesis adalah sebagai berikut :

- Bila $F_{\text {hitung }}>F_{\text {tabel }}$ atau nilai sig $\mathrm{F}<0,05: \mathrm{H}_{0}$ ditolak

- Bila $F_{\text {hitung }}<F_{\text {tabel }}$ atau nilai sig $F>0,05: \mathrm{H}_{0}$ tidak ditolak

Artinya variabel-variabel independent mempunyai pengaruh terhadap variabel dependent. Uji $\mathrm{F}$ untuk pengujian terhadap koefisien regresi secara simultan terhadap hipotesis.

- $\mathrm{H}_{0}$ : faktor pengaruh yang terdiri dari Keuangan (X1), Material (X2), Tenaga Kerja (X3), Peralatan (X4), Metode Pelaksanaan (X5) dan Perubahan Desain (X6) dan Lingkungan Kerja (X7), tidak berpengaruh secara simultan terhadap Keterlambatan Pelaksanaan Pekerjaan ( $Y)$.

- $\mathrm{H}_{1}$ : faktor pengaruh yang terdiri dari Keuangan (X1), Material (X2), Tenaga Kerja (X3), Peralatan (X4), Metode Pelaksanaan (X5) dan Perubahan Desain (X6) dan Lingkungan Kerja (X7), berpengaruh secara simultan terhadap Keterlambatan Pelaksanaan Pekerjaan (Y).

- Digunakan F-test dengan $\mathrm{a}=10 \%$ dengan penjelasan :

Hipotesis :

$$
H o: \beta 1=\beta 2=\beta 3=\beta 4=\beta 5=\beta 6=\beta 7=0
$$

Artinya tidak ada pengaruh yang signifikan anatara variabel $X 1, X 2, X 3, X 4, X 5, X 6, X 7$ secara simultan terhadap variabel $Y, \mathrm{Ha}$ : Ada $\beta 1 \neq 0$. Artinya ada pengaruh yang signifikan anatara variabel $X 1, X 2, X 3, X 4, X 5, X 6, X 7$ secara simultan terhadap variabel $Y$

Dasar pengambilan keputusan :

Jika $\mathrm{p} \leq 0,05$ maka Ha diterima dan Ho ditolak

Jika $\mathrm{p}>0,05$ maka Ha ditolak dan Ho diterima.

Pengujian pengaruh variabel bebas secara parsial terhadap variabel terikat.

Uji t dilakukan untuk mengetahui pengaruh : Material (X1), Peralatan (X2), Tenaga Kerja (X3), Keuangan (X4), Metode Pelaksanaan (X5) dan Perubahan Desain (X6) dan Lingkungan Kerja (X7), digunakan uji t dengan rumus sebagai berikut :

$$
t_{\text {hitung }}=\frac{\beta}{\operatorname{se}\left(\beta_{1}\right)}
$$

dimana:

$\mathrm{t} \quad=\mathrm{t}_{\text {hitung regresi }}$

$\beta_{\mathrm{i}} \quad=$ koefisien regresi

$\operatorname{se}\left(\beta_{i}\right)=$ standar deviasi dari variabel

- Jika $t_{\text {hitung }}>\mathrm{t}_{\text {tabel }}$ pada taraf uji $5 \%$ maka $\mathrm{H}_{0}$ ditolak dan $\mathrm{H}_{1}$ diterima, artinya variabel-variabel bebas berpengaruh terhadap variabel terikat. Jika : $\mathrm{t}_{\text {hitung }}>\mathrm{t}_{\text {tabel }}$ atau nilai sig $\mathrm{t}<0,05: \mathrm{H}_{0}$ ditolak, $\mathrm{t}_{\text {hitung }}<\mathrm{t}_{\text {tabel }}$ atau nilai sig $\mathrm{t}<$ $0,05: \mathrm{H}_{0}$ tidak ditolak.

Uji t ini digunakan untuk menguji hipotesis yaitu :

- $\mathrm{H}_{0}$ : faktor Keuangan (X1), Material (X2), Tenaga Kerja (X3), Peralatan (X4), Metode Pelaksanaan (X5) dan Perubahan Desain (X6) dan Lingkungan Kerja (X7), tidak berpengaruh secara simultan terhadap Keterlambatan Pelaksanaan Pekerjaan ( $Y$ ).

- $\mathrm{H}_{1}$ : faktor Keuangan (X1), Material (X2), Tenaga Kerja (X3), Peralatan (X4), Metode Pelaksanaan (X5) dan Perubahan Desain (X6) dan Lingkungan Kerja (X7), berpengaruh secara simultan terhadap Keterlambatan Pelaksanaan Pekerjaan (Y).

Digunakan t-test dengan $\mathrm{a}=5 \%$ dengan penjelasan :

Hipotesis :

Ho : $\beta 1=0$

Artinya tidak ada pengaruh positif yang signifikan antara variabel $X$ secara parsial terhadap variabel $Y$

$\mathrm{Ha}: \beta 1>0$ Artinya ada pengaruh positif yang signifikan antara variabel $X$

secara parsial terhadap variabel $Y$

Dasar pengambilan keputusan :

Jika $\mathrm{p} \leq 0,05$ maka Ha diterima dan Ho ditolak

Jika $\mathrm{p}>0,05$ maka Ha ditolak dan Ho diterima 
Uji hipotesis dilakukan dengan signifikansi atau taraf kesalahan $5 \%$ dengan pertimbangan bahwa penelitian ini merupakan penelitian dengan metode survei.

Uji-t yang dilakukan dalam analisa regresi pada paket SPSS R 12 bersifat dua arah, sedangkan hipotesis uji-t yang dirumuskan pada penelitian satu arah. Untuk nilai $\mathrm{p}$-value yang didapatkan dibagi dua, sehingga hasil pengujian dengan tingkat yang bersifat satu arah dapat diterapkan untuk uji yang bersifat dua arah.

\section{Uji asumsi model regresi}

Untuk mendapatkan parameter-parameter estimasi dari model dinamis yang dipakai, dalam penelitian ini digunakan metode penaksiran OLS (Ordinary Least Square). Penggunaan metode ini disertai dengan asumsi-asumsi yang mendasarinya. Asumsi-asumsi tersebut yaitu: Normalitas, Multikolinearitas dan Homoskedastisitas.

\section{Asumsi normalitas}

Untuk menguji apakah sampel penelitian merupakan jenis distribusi normal maka digunakan pengujian KolmogorovSmirnov Goodness of Fit Test terhadap masing-masing variabel. Hipotesis dalam pengujian ini adalah :

$\mathrm{H}_{0}: \mathrm{F}_{(\mathrm{x})}=\mathrm{F}_{0(\mathrm{x})}$, dengan $\mathrm{F}_{(\mathrm{x})}$ adalah fungsi distribusi populasi yang diwakili oleh sampel, dan $\mathrm{F}_{0(\mathrm{x})}$ adalah fungsi distribusi suatu populasi berdistribusi normal.

$\mathrm{H}_{1}: \mathrm{F}_{(\mathrm{x})} \neq \mathrm{F}_{0}(\mathrm{x})$ atau distribusi populasi tidak normal.

Pengambilan keputusan apakah Ho diterima atau ditolak didasarkan atas (Santoso, 2001):

- Jika Probabilitas $>0,05$, maka $\mathrm{H}_{0}$ diterima.

- Jika Probabilitas <0,05, maka $\mathrm{H}_{0}$ ditolak.

\section{Asumsi multikolinearitas}

Metode yang digunakan untuk mendeteksi adanya multikolinearitas dalam penelitian ini dengan menggunakan tolerance and variance inflation factor (VIF) (Aliman, 2000). Rule of thumb digunakan sebagai pedoman jika VIF dari suatu variabel melebihi 10, di mana hal ini terjadi ketika nilai $R^{2}$ melebihi 0,90 maka suatu variabel dikatakan berkorelasi sangat tinggi. Untuk mengetahui besarnya VIF digunakan rumus 2.4

\section{Asumsi homoskedastisitas}

Secara matematis asumsi ini dapat dituliskan dengan menggunakan rumus 2.5. Adapun metode yang akan di bahas disini yaitu metode Korelasi Rank Spearman. Sesuai dengan namanya, metode ini menggunakan korelasi peringkat $X$ dan |ei|. Koefisien korelasi Spearman dirumuskan sesuai rumus 2.6

Tingkat signifikan koefisien korelasi $r_{s}$ yang didapatkan dengan rumus di atas diuji dengan statistik uji t dengan menggunakan rumus 2.7

Jika nilai $\mathrm{t}$ yang dihitung melebihi nilai t kritis, kita bisa menerima hipotesis adanya sifat heteroskedastisitas, atau dengan kata lain asumsi homoskedastisitas tidak terpenuhi.

\section{Analisa strategi dalam upaya mengatasi keterlambatan pelaksanaan pekerjaan proyek}

Langkah-langkah penentuan strategi adalah sebagai berikut :

a. Melihat hasil analisis regresi linier berganda terhadap variabel-variabel independen yang memiliki nilai signifikan.

b. Menentukan variabel independen (Faktor) yang paling berpengaruh dominan terhadap keterlambatan pelaksanaan proyek. Variabel yang paling dominan adalah variabel yang berpengaruh signifikan dan memiliki nilai Koefisien $\beta$ yang paling besar.

c. Dari hasil diatas, maka dapat ditentukan strategi untuk mengatasi agar tidak terjadi keterlambatan pelaksanaan proyek

\section{HASIL DAN PEMBAHASAN}

Hasil olahan data tersebut digunakan menjawab pertanyaan pada rumusan masalah.

Pengolahan data hendaknya memperhatikan jenis data yang dikumpulkan dengan berorientrasi pada tujuan yang hendak dicapai. Ketepatan dalam teknik analisa sangat mempengaruhi ketepatan hasil penelitian. Adapun teknik analisis data yang digunakan adalah analisis faktor dan analisis regresi linier berganda. Dimana data hasil kuesioner dengan rentang 1 sampai dengan 4 dari masing-masing variabel tersebut kemudian diskor ulang, sehinggga dari masing-masing variabel yang mengandung beberapa indikator akan menghasilkan satu nilai skor saja yang selanjutnya dianalisis dengan menggunakan analisis faktor dan analisis regresi linier berganda. Pengolahan data dikerjakan dengan bantuan program Statistical Package for Sosial Science (SPSS) for Windows.

Strategi berdasarkan Prioritas pada faktor Lingkungan Kerja. 
Tabel 1. Strategi berdasarkan Prioritas pada faktor Lingkungan Kerja.

\begin{tabular}{|c|c|c|}
\hline $\begin{array}{l}\text { Variabel } \\
\text { Manifes }\end{array}$ & Keterangan & Strategi \\
\hline $\mathrm{X} 7.1$ & $\begin{array}{l}\text { Sering } \\
\text { terjadi hujan }\end{array}$ & $\begin{array}{l}\text { Pada saat pembangunan ditemukan bahwa sering terjadi hujan pada musim } \\
\text { penghujan sehingga owner harus segera membuat kerangka acuan kerja (KAK) } \\
\text { dan spesifikasi teknis sesuai dengan perencanaan yang lebih lengkap dan teliti } \\
\text { serta mengikuti dan mengejar ketinggalan time scedulle kurva } S \text { yang sudah } \\
\text { ditentukan, sehingga kontraktor dapat melaksanakan pekerjaan dengan metode } \\
\text { pelaksanaan yang tepat. }\end{array}$ \\
\hline $\mathrm{X} 7.2$ & $\begin{array}{l}\text { Kondisi } \\
\text { lokasi } \\
\text { tempat kerja }\end{array}$ & $\begin{array}{l}\text { Pada saat pembangunan ditemukan bahwa kontraktor kesulitan dalam menaruh } \\
\text { barang dan peralatan yang digunakan dalam membangun Dom Unisma sehingga } \\
\text { owner membantu menyelesaikan dengan perencanaan yang lebih lengkap dan } \\
\text { teliti. sehingga kontraktor dapat melaksanakan pekerjaan dengan tepat. }\end{array}$ \\
\hline $\begin{array}{l}\text { Variabel } \\
\text { Manifes }\end{array}$ & Keterangan & Strategi \\
\hline $\mathrm{X} 7.3$ & $\begin{array}{l}\text { Keadaan } \\
\text { Topografi }\end{array}$ & $\begin{array}{l}\text { Pada pelaksanaan pekerjaan di temukan bahwa kontraktor kesulitan akses keluar } \\
\text { masuk kendaraan dengan baik, Waktu Ngecor dan menaruh material yang } \\
\text { dibuuhkan. sehingga menguras waktu yang banyak dalam memperbaiki akses } \\
\text { jalan menuju Dom Unisma. Langkah yang harus di ambil adalah kontraktor harus } \\
\text { membuat analisa baik dalam penggunaan peralatan, bahan ataupun tenaga } \\
\text { sehingga tepat waktu dan tepat biaya. }\end{array}$ \\
\hline
\end{tabular}

Sumber: Olah data

\section{KESIMPULAN}

1) Berdasarkan hasil Uji $F$ secara simultan Faktor-faktor yang mempengaruhi keterlambatan proyek secara signifikan adalah variabel Keuangan (X1), Material (X2), Sumber Daya Manusia (X3), Peralatan (X4), Metode pelaksanaan (X5), dan perubahan desain (X6) dari Lingkungan kerja (X7) dengan hasil pengujian $F$ hitung $>F$ tabel $(5,633>2,390)$ dan berdasarkan uji t vaktor yang berpengaruh secara signifikan terhadap keterlambatan proyek adalah variabel Sumber daya manusia (X3) dengan hasil pengujian $t$ hitung $>t$ tabel $(2,700>1,699)$ dan $\mathrm{H}_{\circ}$ Ditolak dan $\mathrm{H}_{1}$, dan selanjutnya pada variabel Lingkungan (X7) dengan hasil $t$ hitung $>t$ tabel $(4,580>1,699)$ dan $\mathrm{H}_{\mathrm{o}}$ Ditolak.

2) Strategi yang harus dilakukan kontraktor dengan keterbatasan Lingkungan kerja yang sempit yaitu membuat Cetakan Tribun di luar Area, Membuat Kerangka Atap di luar Area. Dan membuat Cetakan Kusen di luar Area. sediakan shop drawing untuk membuat kerangka acuan kerja (KAK) dan spesifikasi teknis sesuai dengan perencanaan yang lebih lengkap dan teliti serta mengikuti dan mengejar ketinggalan time scedulle kurva $\mathrm{S}$ yang sudah ditentukan, Menyelesaikan dengan perencanaan yang lebih lengkap dan teliti, Mapping suatu pekerjaan untuk membuat analisa baik dalam penggunaan peralatan, bahan ataupun tenaga sehingga tepat waktu, mutu dan biaya.

\section{DAFTAR PUSTAKA}

Arikunto, S, 2006. Prosedur Penelitian, Edisi Revisi ke VI, Penerbit Rineka Cipta Jakarta.

Asiyanto, 2008. Metode Konstruksi Gedung Bertingkat, UI Press, Jakarta.

Azwar, 1986. Reliabilitas dan Validitas Interpretasi dan Kompulasi, Liberty, Yokyakarta.

Barrie S. Donald and J.R. Paulson C. Boyd, 1984, Manajemen Konstruksi Profesional, Edisi II, Penerbit Erlangga, Jakarta.

Benoref. Supranto, 2001, Pengukuran Tingkat Kepuasa Pelanggan, Rineka Cipta, Jakarta.

Bimo, Walhito, 2010. Teori Motivasi dan analisis pengukuran, Bumi Aksara, Jakarta.

Cooper dan Schndler, 2006. Bussines Research Methods 9th edition, Mc Grow Hill International Edition, Jakarta.

Dipohusodo I, 1995. Manajemen Proyek dan Konstruksi, Edisi Ketujuh, Penerbit Kanisius Yogyakarta.

Djajan, 1986. Pengantar Metode Statistik II, LP3ES, Jakarta.

Hargono Edi,D,Putranto,2013, Diktat Bahan Kuliah Matematika Terapan (Statistik). ITN Malang, Malang.

Ervianto, W.I, 2003, Manajemen Proyek Konstruksi, Penerbit Andi, Jogjakarta.

Ghozali I, M.Com, Akt, 2006, Aplikasi Analisis Multivariate Dengan Program SPSS, Badan Penerbit Universitas Diponegoro, Semarang.

Malhotra, N. K, 1996, Marketing Research an Applied Orientation, Prentice Hall International. London.

Nazir.M,2005, Metode Penelitian, Ghalia Indonesia. Jakarta.

Nugraha, 1985, Metode Statistika, Bumi Aksara. Jakarta.

O'brien, 1976, Sistem Informasi Manajemen, Salemba. Jakarta. 
Peraturan Mentri Pekerjaan Umum, No45/PRT/M/2007, Pedoman Teknis Pembangunan Gedung Negara.

Riduwan, 2005. Skala Pengukuran Variabel-Variabel Penelitian, Alfabeta, Bandung.

Singarimbun, Masri \& Sofian Effendi, 2006, Metode Penelitian Survai, LP3ES, Jakarta.

Soeharto, I, 2001. Manajemen Proyek Dari Konseptual Sampai Operasional. Erlangga. Jakarta.

Sugiyono, 2006, Statistika untuk Penelitian.CV ALFABETA. Bandung.

Soeharto, Iman., 1995. Manajemen Proyek Dari Konseptual Sampai Operasional.Erlangga, Jakarta.

Sugiharto, Situnjak, 2006. Graha Ilmu, LISREL, Yokyakarta.

Wateno Oetomo,2014. Manajemen Proyek dan Konstruksi Bagian I, Penerbit PT. Mediatama Saptakarya, Jakarta.

Messah, 2008, Pengendalian Waktu dan Biaya Pekerjaan Konstruksi Sebagai dampak dari perubahan desain, Jurnal Teknik Sipil Vol.II. No 2, ITN Malang

Dannyanti, E., 2010. Optimalisasi Pelaksanaan Proyek dengan Metode PERT dan CPM. Skripsi, Fakultas Ekonomi, Universitas Diponegoro, Semarang.

Dipohusodo, I.; 1996. Manajemen Proyek dan Konstruksi 2, Kanisius, Yogyakarta.

Proboyo, B; 1998. Keterlambatan Waktu Pelaksanaan Proyek; Klasifiasi dan Peringkat dari Penyebab-penyebabnya, Universitas Kristen Petra, Surabaya.

Solimun, Nurjannah dan A. A. Rinaldo. 2006. Pemodelan Persamaan Struktural Pendekatan Aplikasi PLS dan SEM. Fakultas MIPA dan Program Pasca Sarjana Universitas Brawijaya Malang.

Wahyudi, R dan Indra Yono, C; 2006.Pengaruh Keterlambatan Proyek terhadapPembekakan Biaya Proyek. Universitas Kristen Petra, Surabaya.

Wijayanthi,S; 2008. Faktor-faktor Penyebab Keterlambatan Waktu Pembangunan Proyek Gedung Negara di Lingkungan Pemerintah Kota Kediri, ITS.

Arditi da Patel ,1989, Kajian Pemilihan Pemenang Tender Konstruksi Di Surabaya, Tesis ITS Surabaya.

Gunawan, 2012, Analisis Faktor-Faktor Yang Mempengaruhi Keterlambatan Waktu Pada Proyek Pembangunan Gedung Olahraga Di Kota Pasuruan Jawa Timur Dan Strategi Penanggulangannya, Tesis ITN Malang.

Rafael, 2010, Faktor-Faktor Yang Mempengaruhi Penambahan Waktu Terhadap Pelaksanaan Kontrak (Studi Kasus : Pembangunan Proyek-Proyek DiCipta Karya Dinas Pekerjaan Umum Kabupaten Manggarai Barat-Nusa Tenggara Timur). Tesis ITN Malang.

Satriawansyah, 2012, Faktor-Faktor Yang Memepengaruhi Keterlambatan Pelaksanaan Pekerjaan Pada Proyek Pembangunan Gedung Bertingkat Di Kabupaten Sumbawa Nusa Tenggara Barat, Tesis ITN Malang.

Supranto, J, 2001, Statistik Teori Dan Aplikasi Jilid 2, Penerbit Erlangga JakartaCara Menghitung Uji Validitas Dan Uji Reliabilitas Instrumen Skripsi Kuantitatif dengan SPSS. Diakses dari http://devamelodica.com/caramenghitung-uji-validitas-dan-uji-reliabilitas-instrumen-skripsi-kuantitatif-dengan-spss/. 